\title{
On the Structural Organization of the Transcriptional Unit in Animal Chromosomes
}

\author{
Georgiy P. Georgiev, Alexandr Ja. Varshavsky, Alexej P. Ryskov, and \\ ROBERT B. ChURCH* \\ Institute of Molecular Biology, Academy of Sciences of the U.S.S.R., Moscow, U.S.S.R.
}

Three levels of genome organization in eukaryotes are considered in this paper: (1) the structure ${ }^{\cdot}$ of the transcriptional unit (or transcripton); (2) the arrangement of proteins along unfolded chromosomal DNA in chromatin; and (3) the mode of DNA packing in the chromatin.

\section{The Structure of Transcripton}

The model. Briefly, according to a model proposed previously (Georgiev, 1969) and slightly modified now (Fig. 1), the transcripton consists of a rather small structural zone containing one or a few structural genes and a large acceptor zone, which does not carry structural information but contains the acceptor sites interacting with structural and regulatory proteins of the chromosome. The structural gene is localized at the end of the transcripton. The whole transcripton, including the acceptor zone, is transcribed into giant precursor of mRNA (pre-mRNA). The initiation and progression of the transcripton is under the control of interaction of regulatory proteins with acceptor sites. Giant pre-mRNA is formed, which consists of the informative part near the $3^{\prime}$ end (mRNA) and the noninformative part (pseudo-mRNA). During the processing, the latter is destroyed, whereas the informative part, or true mRNA, is conserved and transferred into the cytoplasm.

Some acceptor sites are reiterated. The identical copies may be present either in the same transcripton or in different transcriptons. The latter allows one regulatory factor to switch on or off many different transcriptons simultaneously.

This model is in agreement with many facts that have appeared during the last years, in particular with some genetic data. Complementation analysis demonstrated that one band in Drosophila corresponds to one complementation unit, probably to one structural gene (Judd et al., 1972). On the other hand, the amount of DNA per band for haploid set is much higher than required for coding one protein molecule (Beermann, 1972). In addition,

\footnotetext{
* Present address: Calgary University, Calgary, Canada.
}

renaturation experiments demonstrated that such structural genes as genes for hemoglobin and fibroin are represented by only one or a few (not more than three) copies per genome (Bishop et al., 1972, Bishop and Rosbash, 1973, Suzuki et al., 1972).

These facts taken together show that a significant portion of DNA in eukaryotes does not carry structural information. However, the main data on the structure of the transcripton have originated from studies on the structure of pre-mRNA.

Structural organization of pre-mRNA. PremRNA (synonyms: dRNA, DNA-like RNA; HnRNA, heterogeneous RNA; mIRNA, messengerlike RNA) was discovered in 1962 (Georgiev and Mantieva, 1962) and shown to be a precursor of mRNA. The molecular weight of the nuclear premRNA is much higher than that of cytoplasmic mRNA (Samarina, 1964, Samarina et al., 1965, Yoshikawa et al., 1964; Scherrer and Marcaud, 1965). Competitive hybridization experiments demonstrated that all rapidly hybridizing sequences of $\mathrm{mRNA}$ are present in pre-mRNA, although these sequences represent only a small part of all rapidly hybridizing sequences of pre-mRNA (Georgiev, 1966; Arion and Georgiev, 1967; Shearer and McCarthy, 1967; Scherrer and Marcaud, 1968). Lindberg and Darnell (1970) showed that nascent SV40-specific RNA in SV40 transformed cells is a part of giant nuclear RNA, whereas in cytoplasm it is observed as a rather low molecular weight mRNA. Later, poly(A) sequences 150-250 nucleotides long were demonstrated in both nuclear premRNA and mRNA of the cytoplasm (Lee et al., 1971; Edmonds et al., 1971; Darnell et al., 1971), confirming a precursor-product relation between them.

Recently the existence of hemoglobin mRNA sequence in the giant nuclear pre-mRNA from erythroblasts was proved by hybridization of hemoglobin anti-mDNA to giant pre-mRNA (Imaizumi et al., 1973) and also by experiments in which induction of hemoglobin synthesis in frog oocytes occurred upon injection of pre-mRNA (Williamson et al., 1973). In both cases, the data 

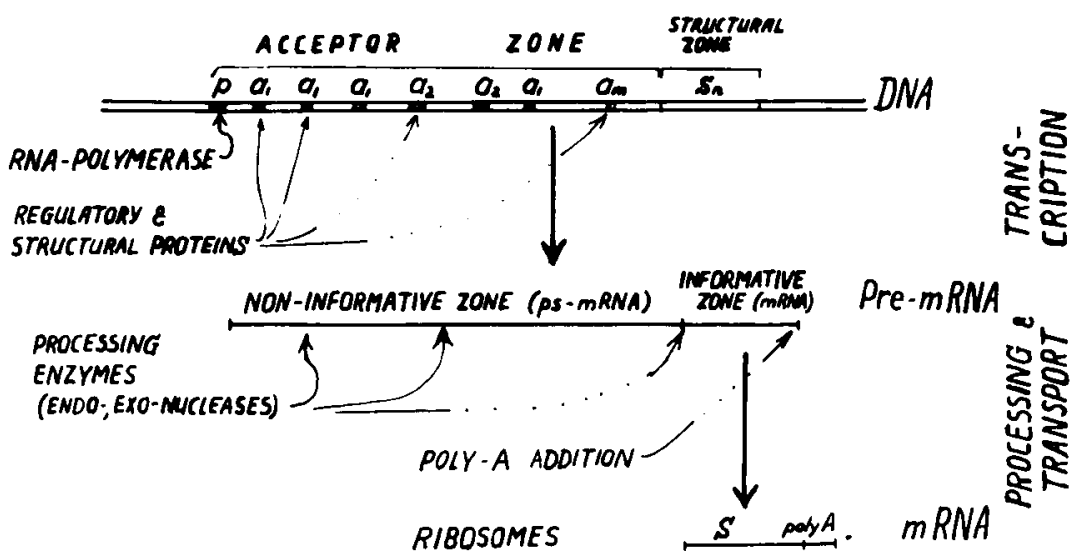

Figure 1. A slightly modified model of a transeripton in eukaryotes (Georgiev, 1969). $(p)$ Promotor; $\left(a_{1}-a_{m}\right)$ acceptor sites, $m \geqslant 1 ;\left(s_{\mathrm{n}}\right)$ structural gene(s); usually $n=1$. indicated that the total amount of mRNA sequences in pre-mRNA is low and corresponds to approximately one mRNA sequence per one giant premRNA molecule.

The next question is: Where is the mRNA sequence localized in the pre-mRNA chain? To answer this question, the hybridization properties of 5 '-end and $3^{\prime}$-end sequences of pre-mRNA were studied. 5 -end sequences were detected by the presence of triphosphorylated nucleotide. After alkaline hydrolysis, pppNp group is formed, and these groups were really found in a fraction of giant pre-mRNA $(S \geqslant 35)$ (Ryskov and Georgiev, 1970). $3^{\prime}$ ends were labeled chemically using periodate oxydation$\left[{ }^{3} \mathrm{H}\right]$ borohydride reduction technique (Leppla et al., 1968). After alkaline hydrolysis, labeled nucleoside derivatives were isolated and used as indicators of a $3^{\prime}$-end group (Coutelle et al., 1971).

Double-labeled pre-mRNA was broken to short segments and tested in hybridization with DNA in the presence or absence of nonlabeled $\mathrm{mRNA}$ competitor (Table 1). It was found that at DNAdriven $\mathrm{C}_{0} \mathrm{t}$ of about $1-10$, both $5^{\prime}$-end and $3^{\prime}$-end sequences hybridize more efficiently than total RNA, indicating the existence of reiterated sequences at both ends. Polysomal mRNA very poorly competes with giant pre-mRNA, but it strongly inhibits the hybridization of $3^{\prime}$-end sequences. This result indicated the existence of mRNA at the $3^{\prime}$ end of the precursor (Coutelle et al., 1970; Georgiev et al., 1972). This main conclusion from experiments on hybridization of end sequences is in good agreement with the abovementioned model.

As most of the structural genes are nonreiterated, it seems unlikely that the short reiterated sequence at the $3^{\prime}$ end is a copy of the structural gene. One could suggest that it is a special auxiliary sequence that functions as a terminator or as a signal for poly(A) addition. This sequence is transferred to the cytoplasm, and its presence in mRNA may explain the hybridizability of some part of $\mathrm{mRNA}$ to DNA at low $\mathrm{C}_{0} \mathrm{t}$ values.

The hybridization of reiterated sequences at the $5^{\prime}$ end of the pre-mRNA molecule is not inhibited by addition of polysomal RNA (mRNA), i.e., this

Table 1. Hybridization and Competition Properties of $5^{\prime}$ and $3^{\prime}$ Ends of Giant Pre-mRNA from Ehrlich Ascites Carcinoma Cells

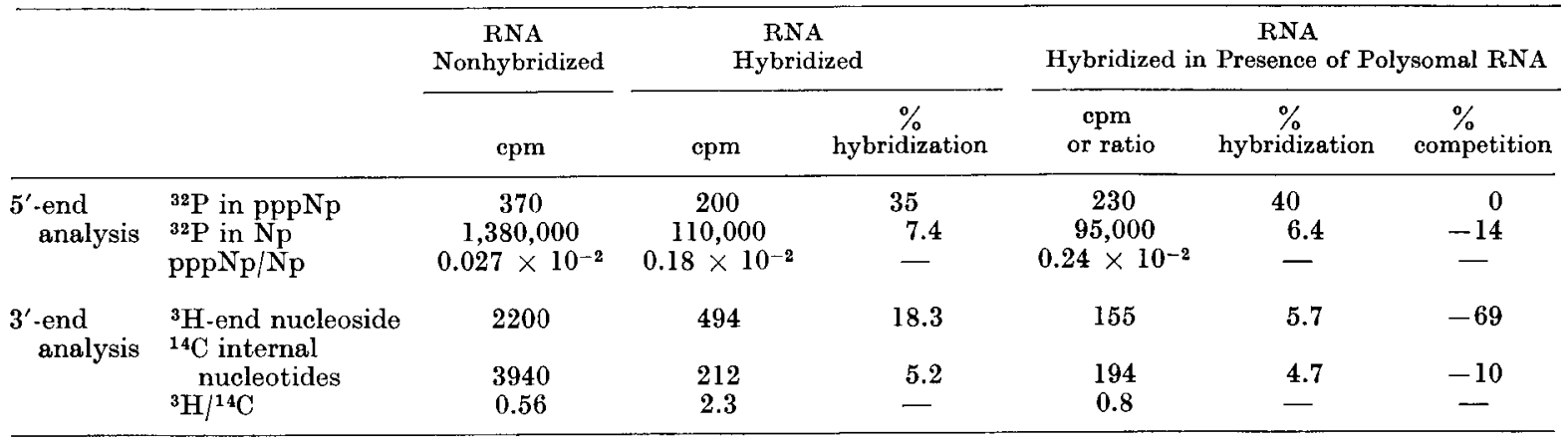

The isolation and labeling of RNA and its hybridization and analysis of $5^{\prime}$-end and $\mathbf{3}^{\prime}$-end groups were performed as described earlier (Georgiev et al., 1972). Data of two typical experiments at intermediate $C_{0} t$ values. 
part of the pre-mRNA does not contain mRNA sequence (Table 1 ).

$3^{\prime}$-end localization of $\mathrm{mRNA}$ in the pre-mRNA was confirmed by poly(A) studies. Long chains of poly (A) ( $\sim 150-250$ nucleotides) were found at the $3^{\prime}$ ends of mRNA and nascent pre-mRNA. They are added exzymatically to the $3^{\prime}$ end of completed premRNA and are conserved upon the transfer of mRNA to polysomes (Edmonds et al., 1971; Darnell et al., 1971; Lee at al., 1971; Mendecki et al., 1972; Molloy et al., 1972b).

Taken together, these facts prove the $3^{\prime}$-end position of mRNA in pre-mRNA and the absence of mRNA sequences in the $5^{\prime}$ part of the precursor. Thus, the structural gene is localized at the end of the transcripton. The beginning of the transcripton does not contain structural genes.

The question arises as to the nature of the noninformative zone. The approach used was to look for specific sequences in the nucleus-restricted part of the pre-mRNA (pseudo-mRNA).

Some of such specific sequences have been discovered during the last years. These are the reiterated base sequences, the main part of which is concentrated in pseudo-mRNA. It is a very heterogeneous population of sequences. Among them, reiterated $5^{\prime}$-end sequences containing $\mathrm{pppNp}$ groups should be pointed out (Georgiev et al., 1972), although at this moment they have not yet been purified from other reiterated sequences.

Another type of characteristic sequences is a hairpin-like structure typical of pseudo-mRNA (Ryskov et al., 1972, 1973; Jelinek and Darnell, 1972), some properties of which will be described in the following section. Finally, urydilate-rich sequences $\sim 30$ nucleotides long, also present exclusively in nascent pre-mRNA, were described (Burdon and Shenkin, 1972; Molloy et al., 1972a). All these sequences are degraded in the course of pre-mRNA processing and absent from mature mRNA. Their investigation may give information about the topography and significance of the noninformative part of the pre-mRNA.

Double-stranded hairpin-like structures in pre-mRNA. It was shown previously that premRNA contained sequences resistant to RNase at ionic strength $\geqslant 0.1$ (Ryskov et al., 1972, 1973; Jelinek and Darnell, 1972), probably corresponding to double-stranded cellular RNA (dsRNA) discovered by Harel and Montagnier (1971). RNaseresistant material was separated into two peaks by gel filtration on Sephadex G-75 (Fig. 2). Peak I contains poly $(A)$ and long dsRNA segments $(\sim 100$ base pairs) and peak II, dsRNA of lower chain length (10-20 base pairs). Poly(A) comprises the

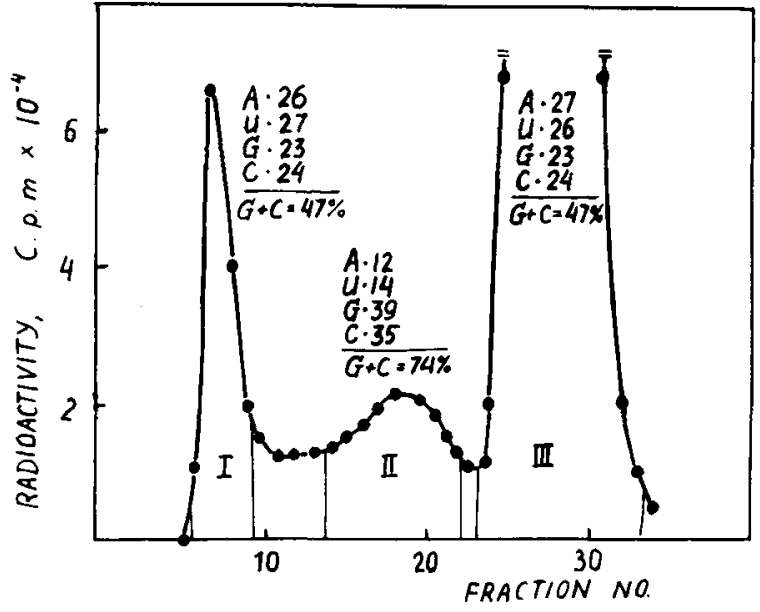

Figure 2. Isolation of double-stranded, hairpin-like structures from heavy pre-mRNA. Heavy pre-mRNA was isolated from Ehrlich ascites carcinoma cells (labeled with ${ }^{32} \mathrm{P}$ during $1 \mathrm{hr}$ ) with the aid of hot phenol fractionation technique (Georgiev and Mantieva, 1962) followed by sucrose gradient centrifugation. Heavy fraction $(\geqslant 45 \mathrm{~S})$ was collected and treated with a mixture of pancreatic RNase and T1 RNase in $2 \times$ SSC during $30 \mathrm{~min}$ at $37^{\circ} \mathrm{C}$ (Ryskov et al., 1972). The hydrolysate was treated with pronase and then loaded on a Sephadex G-75 column equilibrated with $0.3 \mathrm{M}$ acetate, $\mathrm{pH} 7$. The fractions were collected and counted using the Cherenkov effect. The material of peaks I ("long hairpins"), II ("short hairpins"), and III (hydrolyzed material) were collected. Poly(A) was removed from peak I according to Lee et al. (1971). It comprises about $10 \%$ of the material. Each sample was hydrolyzed with $0.5 \mathrm{~N} \mathrm{KOH}$ overnight, and base com. position was detected on the basis of radioactivity of nucleotides separated electrophoretically.

main part of peak $I$ in the light pre-mRNA (10-30 $\mathrm{S})$, whereasin the heavy pre-mRNA $(\geqslant 30-40 \mathrm{~S})$, the main part of peak I belongs to dsRNA. Poly(A) was separated from dsRNA by the technique of Lee et al. (1971). Both dsRNAs have symmetrical base composition: in peak $\mathrm{I}$ it is $\mathrm{AU}$-rich and in peak II very GC-rich.

The double-stranded structure of RNase-stable material was proved by means of chromatography on hydroxyapatite and also in melting experiments. If pre-mRNA untreated with RNase is melted by heating and then rapidly cooled, dsRNA is reconstituted. This suggests the hairpin-like structure of dsRNA. Some other confirmations will be presented below. For this reason, we designate the material of peak I as "long hairpins" and the material of peak II as "short hairpins." Long hairpins account for about $1 \%$ of the heavy pre-mRNA. The content of short hairpins is somewhat higher $(\sim 2 \%)$, and they are present also in the light pre-mRNA. In dsRNA isolated after RNase treatment the loop is nicked, and melting leads to a separation of the complementary strands, thus making possible reassociation and hybridization experiments. 

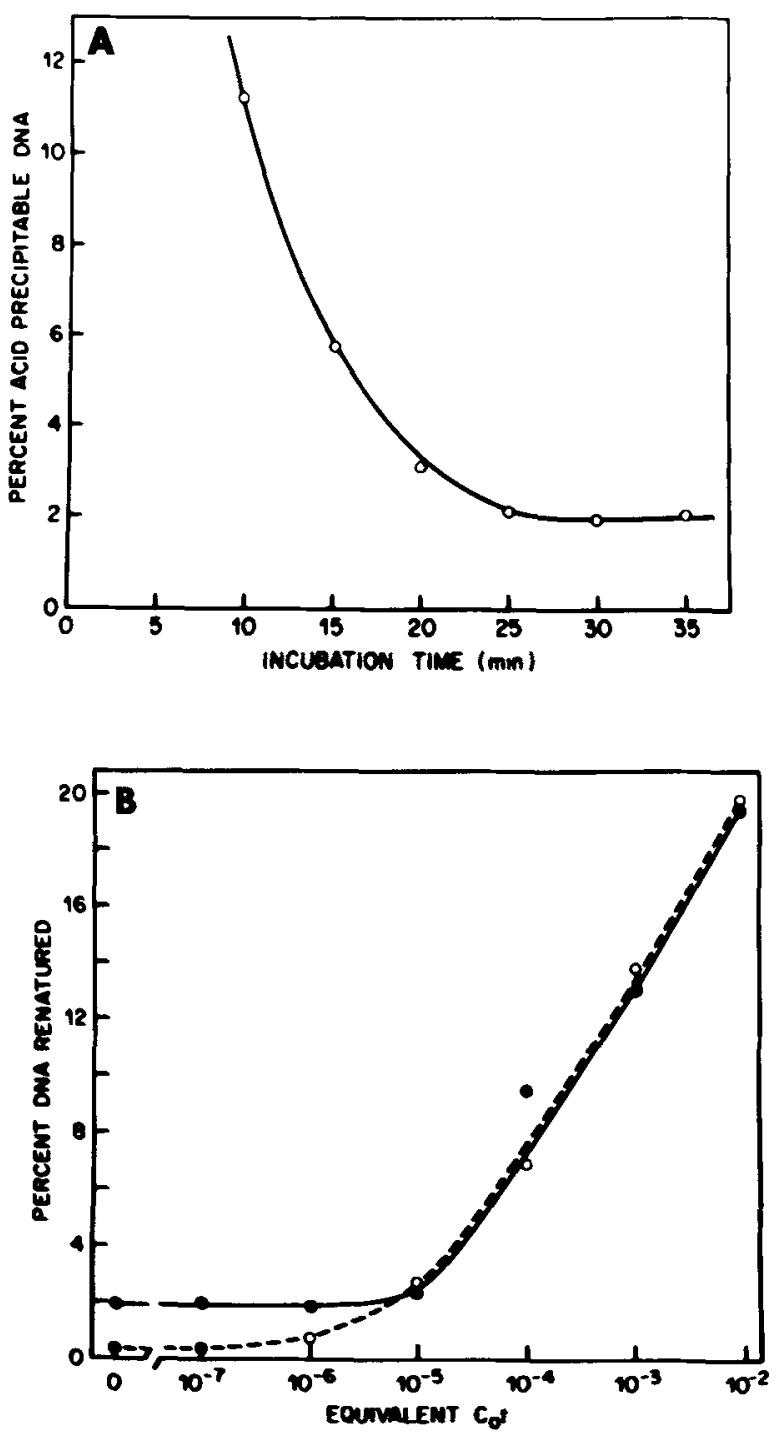

Figure 3. Demonstration of the reverted repetitions in mouse DNA. Highly labeled $\left[{ }^{3} \mathbf{H}\right]$ DNA from mouse $L$ cells was sheared, denatured by heating, then renatured either in $0.12 \mathrm{~m}$ phosphate buffer or in $0.18 \mathrm{M} \mathrm{NaCl}$ at $60^{\circ} \mathrm{C}$ for various periods to obtain the $\mathrm{C}_{0} \mathrm{t}$ values indicated. After incubation, the sample was diluted with buffer for DNase S1 assay (Sutton, 1971), and DNase S1 was added. After exhaustive digestion, the acid-insoluble material was counted. In some experiments DNA was denatured in the presence of $2 \%$ formaldehyde. The latter was then removed in the cold by rapid gel filtration. DNase $\mathrm{Sl}$ then was added either immediately or after a short incubation at $60^{\circ} \mathrm{C}$. The latter removed methylol groups bound to DNA and allowed reassociation. $(A)$ Kinetics of DNase SI digestion of denatured DNA after annealing at $\mathrm{C}_{0} \mathrm{t}=$ $10^{-7} ;(B)$ renaturation curve for denatured DNA. (-) Denaturation without formaldehyde; $(-\mathrm{O}-)$ denaturation with formaldehyde.

Long hairpins are almost completely absent from light nuclear pre-mRNA, suggesting their rapid destruction in the course of precessing. Both kinds of hairpins are absent from mature mRNA. Thus they are typical of pseudo-mRNA sequences. The experiments described below were carried out mainly with "long hairpins."
To understand the nature of the hairpins, their hybridization and renaturation properties were studied. It was observed that melted dsRNA from the peaks I and II hybridizes efficiently with DNA atlow $\mathrm{C}_{\mathbf{0}} \mathrm{t}$ values (Jelinek and Darnell, 1972; Ryskov et al., 1973). This indicated its transcription from reiterated DNA base sequences. Approximate calculations for the genome of Ehrlich carcinoma cells gave $\sim 500$ different families of hairpins, with $\sim 500$ members in each family.

The next step was the isolation of DNA sequences from which dsRNA was transcribed. It was suggested that they are transcribed from reverted repetitions of DNA. To isolate the latter, extensively sheared, radioactive mouse DNA ( 500 base pairs long) was melted and then renatured at very low $\mathrm{C}_{0}$ t values $\left(\leqslant 10^{-7}\right)$, excluding the renaturation even of the most reiterated sequences, such as satellites, and allowing only the self-renaturation, i.e., the renaturation of covalently linked complementary strands. Single-stranded DNA was then destroyed by DNase S1, which is absolutely specific for single-stranded DNA (Ando, 1966; Sutton, 1971). Self-renatured sequences survived and were purified from the digested material by hydroxyapatite chromatography. About $2 \%$ of the DNA was stable after annealing at extremely low $\mathrm{C}_{0} \mathrm{t}$ value (Fig. 3B). According to its behavior in hydroxyapatite chromatography and its melting properties, DNase S1-resistant material is represented by dsDNA. The loop in the DNA hairpin survives the DNase Sl treatment, as the melting and rapid cooling does not make the material digestable and does not change its chromatographic behavior on hydoxyapatite. However, if one melts the DNase S1-resistant DNA in the presence of $1 \%$ formaldehyde and then removes free formaldehyde by rapid gel filtration in the cold, it becomes possible to destroy this DNA by DNase S1. Even very short incubation in the absence of formaldehyde (enough to remove methylol groups from DNA) makes the material DNase S1-stable again. The binding of DNA to hydroxyapatite column is changed in the same manner.

It seems very probable that the DNase SIresistant material isolated from denatured DNA has a hairpin-like structure and encodes hairpins of pre-mRNA. The hairpins in denatired DNA correspond to reverted repetitions in native DNA. According to the DNase Sl test, reverted repetitions account for $2 \%$ of the total DNA (Fig. 3A). About half of them may originate from AT-rich satellite, since in purified satellite $10-15 \%$ of the sequences survive the treatment with DNase S1 after denaturation. (Another half belongs to the main component.) Their size is of the same order as the size of long hairpins in the pre-mRNA. Short 
DNA hairpins were not detected in the experiments mentioned. Thus the size and the content of reverted repetitions in DNA and of long hairpins in pre-mRNA appear to be about the same. One hairpin could be found in the pre-mRNA chain of about 20,000 nucleotides long (mol. wt. 6-7 $\times 10^{6}$ ), which corresponds to a $1: 1$ ratio between the number of pre-mRNA molecules and the number of hairpin-like structures. Similarly, one reverted repetition is present per 20,000 base pairs of DNA (mol. wt. $12-15 \times 10^{6}$ ).

To elucidate the relationship between DNA and RNA hairpins, hybridization experiments were carried out. DNA hairpins, melted in the presence of formaldehyde, were fixed on nitrocellulose mem. brane filters and hybridized with denatured dsRNA. In conditions where the RNA-driven $\mathrm{C}_{0} \mathrm{t}$ and DNAdriven $\mathrm{C}_{\mathrm{o}} \mathrm{t}$ were of the same order, similar amounts of RNA were hybridized to DNA and renatured (forming RNA.RNA duplexes) (Table 2). This result qualitatively indicates that at least a significant part of DNA hairpins serve as templates for the synthesis of long hairpins present in pre-mRNA.

To understand a possible role of reverted repetitions in DNA and hairpins in pre-mRNA one needs to know more about the sequence complexity of hairpins and their tissue specificity. A convenient approach to answer these questions is the study of renaturation kinetics of denatured dsRNA or DNA.

Experiments have been performed with dsRNA isolated from heavy pre-mRNA of mouse Ehrlich ascites carcinoma, mouse Krebs ascites carcinoma, and mouse liver cells (Fig. 4). One can see that although there are some differences in the kinetics of reassociation between different preparations of
dsRNA, in all cases two main fractions can be resolved: (1) very rapidly reassociating $R N A$ sequences with $\mathrm{C}_{0} \mathrm{t}_{1 / 2} \sim 2-5 \times 10^{-4}$; and (2) a more heterogeneous fraction of RNA renaturating in a broader interval with $\mathrm{C}_{0} \mathrm{t}_{1 / 2}=0.1-1$.

The calculated complexity of the rapidly renaturating dsRNA is about 100 base pairs. Therefore, this fraction probably consists of only one kind of sequences; i.e., it represents a homogeneous material. Of course the kinetic experiments do not give exact figures, but in any case, the number of different hairpins in this fraction can not exceed two or three.

As all tissues studied contain the very rapidly associating hairpins, the question arises whether the hairpins are different or similar in different tissues. Mixtures were prepared containing a small amount of highly ${ }^{3} \mathrm{H}$-labeled hairpins from one tissue and a much higher amount of low ${ }^{14} \mathrm{C}$-labeled hairpins from another. The mixtures were then incubated in conditions allowing the reassociation of the rapidly renaturating fraction only in lowlabeled hairpins taken in higher concentration. The results obtained (Table 3 ) show the existence of cross reaction between rapidly reassociating hairpins from different tissues. Thus, at least for rapidly reassociating hairpins, there is low, if any, species specificity.

Concerning the physiological role, if any, of the hairpins, one could consider the following possibilities: (1) reverted repetitions in DNA represent the acceptor sites which interact with regulatory proteins, e.g., rapidly reassociating hairpins may be responsible for switching on or off of genes which are active in most of the tissues of a given organism;

Table 2. Hybridization of Long dsRNA Sequences from pre-mRNA Hairpins and from Denatured DNA of Ehrlich Ascites Carcinoma Cells

\begin{tabular}{|c|c|c|c|c|c|c|c|c|c|}
\hline \multirow[b]{3}{*}{ Exp. No. } & \multicolumn{4}{|c|}{ Hybridization Conditions } & \multicolumn{3}{|c|}{ Radioactivity } & \multirow{3}{*}{$\begin{array}{c}\% \text { RNA } \\
\text { hybridized } \\
\text { to DNA }\end{array}$} & \multirow{3}{*}{$\begin{array}{c}\% \text { RNA } \\
\text { Renatured }\end{array}$} \\
\hline & \multirow{2}{*}{$\begin{array}{c}\text { DNA }^{8} \text { hairpins } \\
(\mu \mathrm{g})\end{array}$} & \multirow{2}{*}{$\begin{array}{c}\text { RNA }^{a} \\
\text { hairpins } \\
(\mu \mathrm{g})\end{array}$} & \multirow{2}{*}{$\begin{array}{l}\text { Vol. in } \\
6 \times \text { SSC } \\
(\mathrm{ml})\end{array}$} & \multirow{2}{*}{$\begin{array}{c}\text { Time } \\
\text { (hrs) }\end{array}$} & \multirow[b]{2}{*}{ Hybridized } & \multicolumn{2}{|c|}{ Nonhybridized } & & \\
\hline & & & & & & Total & RNase-stable & & \\
\hline 1 & 0.70 & 0.030 & 0.050 & 2 & 390 & 1000 & 570 & 28 & 41 \\
\hline 2 & 0.30 & 0.025 & 0.020 & 2 & 350 & 740 & 460 & 32 & 42 \\
\hline $\mathbf{3}$ & no DNA & 0.03 & 0.050 & 2 & 5 & 1500 & - & 0.3 & - \\
\hline 4 & total DNA, 70.0 & 0.13 & 2.0 & 0.8 & 400 & 6300 & - & 6 & - \\
\hline
\end{tabular}

RNA-driven $C_{0}$ t value was of about 0.05 ; DNA-driven $C_{0} t$ value was of about 0.1 .

a Specific activities of RNA and DNA preparations were about $50,000 \mathrm{cpm} / \mu \mathrm{g}\left({ }^{32} \mathrm{P}\right)$ and $10,000 \mathrm{cpm} / \mu \mathrm{g}\left({ }^{3} \mathrm{H}\right)$, respectively.

The double-stranded material from pre-mRNA was isolated as described in Figure 2 . The hairpins from denatured [ ${ }^{3} \mathbf{H}$ ]DNA were isolated as described in Figure 3. Double-stranded DNase S1-resistant material was coneentrated and purified by hydroxyapatite chromatography. It was then mixed with nonlabeled, sheared $E$. coli DNA, reprecipitated with ethanol, and denatured by heating in the presence of $3.7 \%$ formaldehyde. The solution was diluted with $6 \times$ SSC to DNA concentration of $0.5 \mu \mathrm{g} / \mathrm{ml}$ and passed through an HA-membrane filter several times. The following treatment was according to Gillespie and Spiegelman (1965). RNA was added in $6 \times \mathrm{SSC}$ and annealed at $65^{\circ} \mathrm{C}$. After annealing, the filter was washed several times with $6 \times \mathrm{SSC}$, treated with RNase $(50 \mu \mathrm{g} / \mathrm{ml})$, again washed with $6 \times$ SSC and then with ethanol, and counted. The supernatant was separated into two parts to determine the total and RNase-stable, acid-insoluble radioactivity. All radioactivity measurements for ${ }^{32} \mathrm{P}$ and ${ }^{3} \mathrm{H}$ were made in a SL 40 Counter (Intertechnique) using a toluenePPO-POPOP scintillator. 


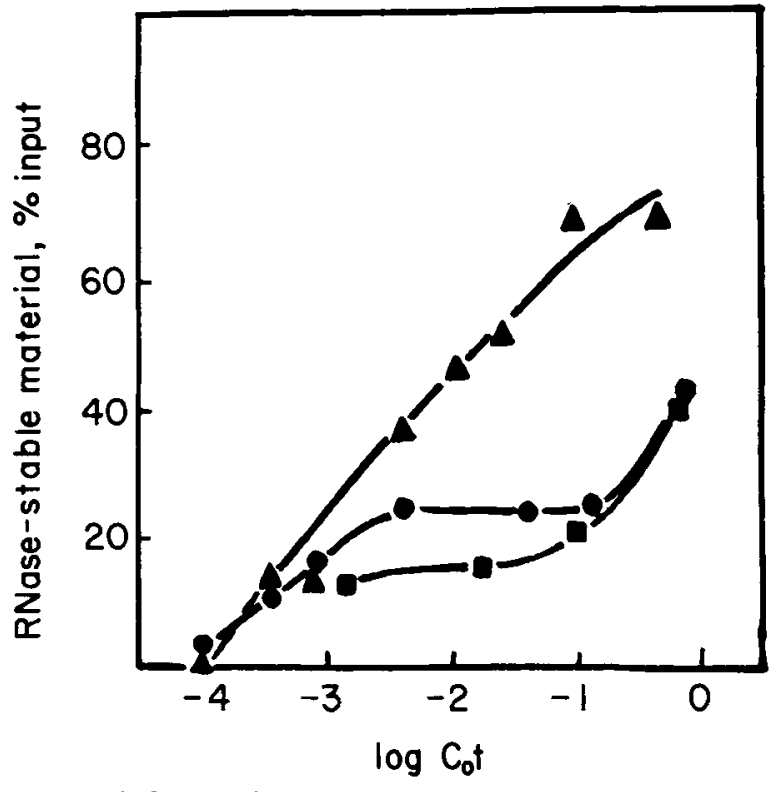

Figure 4. Reassociation of denatured long dsRNA sequences (long hairpins) isolated from heavy pre-mRNA of mouse liver and carcinoma cells. Peak I from Sephadex G-75 eluate (see Fig. 2), corresponding to long dsRNA sequences, was extensively purified from RNase by means of SDS-phenol treatment at $65-70^{\circ} \mathrm{C}$, precipitated by ethanol with tRNA carrier, collected, dissolved in a small volume of water, put in a sealed capillar, and denatured by heating $15 \mathrm{~min}$ in a boiling water bath. The calculation of amount of material was based on the assumption that the specific activity of hairpins is the same as that of the total heavy pre-mRNA. Aliquots of denatured dsRNA were taken, made $2 \times$ SSC, adjusted by $2 \times$ SSC to a required concentration, and incubated in sealed capillars for a specified time to the required $C_{0}$ t. The concentration of RNA was high enough to avoid incubation longer than 6-10 hr. Samples were then divided, and one-half was immediately put on a glass filter containing $5 \%$ TCA, whereas another was treated with RNase mixture (see legend for Fig. 2) and then put on another filter. Both filters were dried by air stream, washed with $5 \%$ TCA and ethanol, and counted. Renaturation was determined as a ratio of RNase-resistant activity to the total activity. Background (4-10\%) was subtracted in all cases. (A) Material from mouse liver; ( $\square$ ) from mouse Ehrlich ascites carcinoma cells; (๑) from mouse Krebs ascites carcinoma cells.

and (2) hairpins in pre-mRNA are sites of processing, in particular the sites which separate mRNA from pseudo-mRNA. After cleavage of the hairpin loop these sequences are separated.

To analyze the second possibility, we studied the hybridization of RNA hairpins with the fractions of nuclear pre-mRNA and cytoplasmic poly(A)containing RNA (mRNA) isolated from Krebs carcinoma cells (Table 4). Denatured ${ }^{3} \mathrm{H}$-labeled dsRNA was annealed at $\mathrm{C}_{\mathrm{o}} \mathrm{t}$ values too low for a significant reassociation. To some of the samples $\left[{ }^{14} \mathrm{C}\right]$ pre-mRNA or mRNA were added, and their influence on the formation of RNase-resistant ${ }^{3} \mathrm{H}$ labeled material was studied. About $20-25 \%$ of $\left[{ }^{3} \mathrm{H}\right]$ RNA became stable, i.e., formed duplexes with pre-mRNA or mRNA added in excess. The data presented in Table 4 suggest that both the very rapidly and less rapidly renaturing hairpins are involved in the association with mRNA and premRNA. As pre-mRNA and mRNA are not placed in denaturing conditions before annealing, their own hairpins, if present, should be in the doublestranded form and therefore be unable to reassociate with added denatured dsRNA. One can conclude that single-stranded regions of pre-mRNA and mRNA contain sequences complementary to branches of some hairpins.

The concentration of sequences interacting with hairpins in mRNA is at least not lower than in premRNA. These data are compatible with the suggestion that hairpins separate mRNA and pseudomRNA sequences in pre-mRNA, and the processing enzymes cut it just in this position. One of the hairpin branches stays bound to mRNA. Of course, another interpretation is possible, namely, that pre-mRNA and mRNA simply contain sequences complementary to one of the hairpin branches.

In these experiments a new property of premRNA was recognized. A significant proportion of sequences in all fractions of pre-mRNA form RNase-resistant duplexes after annealing (Fig. 5). About $20 \%$ of total sequences may be reassociated. This reassociation does not take place at low $\mathrm{C}_{0} \mathrm{t}$, when satellite sequences reassociate. The main fraction of duplexes is formed at intermediate $\mathrm{C}_{0} \mathrm{t}$ values, but some additional reassociation was also found at very high $\mathrm{C}_{0} \mathrm{t}$ values $\left(10^{3}-10^{4}\right)$. Thus about $20 \%$ of the sequences in the pre-mRNA are complementary to each other. This may occur as a result of (1) divergence of reverted repetitions; (2) overlapping of transcriptions which are read in opposite directions; or (3) different directions of transcription in different transcriptons containing the same reiterated sequence. In any case, the existence of complementarity between reiterated sequences and possibly between some unique sequences, in premRNA should be considered upon analysis of data of hybridization experiments.

Let us now summarize briefly the main conclusions on the structure of pre-mRNA.

(1) mRNA is localized at the $3^{\prime}$ end of giant premRNA.

(2) Besides transcript of the structural gene, mRNA contains some additional service sequences at the $3^{\prime}$ end to which poly $(\mathrm{A})$ is added and possibly also some service sequences at the $5^{\prime}$ end; the latter may be complementary to one of the branches of some kinds of hairpins.

(3) The noninformative part of pre-mRNA (pseudo-mRNA) contains many specific sequences that do not carry structural information. Among them are reiterated sequences, many of which are complementary to each other. 
Table 3. Cross Renaturation of Long dsRNA Sequences Isolated from pre-mRNA of Different Mouse Tissues

\begin{tabular}{|c|c|c|c|c|c|c|c|}
\hline \multirow{2}{*}{$\begin{array}{l}{\left[{ }^{3} \mathrm{H}\right] \mathrm{dsRNA} \text { Taken in }} \\
\text { Low Concentration } \\
\text { (tissue \& } \mathrm{C}_{\mathrm{o}} \mathrm{t} \text { value) }\end{array}$} & \multirow{2}{*}{$\begin{array}{c}\text { dsRNA } \\
\text { Taken in Excess } \\
\text { (tissue \& } \mathrm{C}_{\mathrm{o}} \text { t value) }\end{array}$} & \multicolumn{3}{|c|}{ Results of Renaturation Reaction } & \multicolumn{2}{|c|}{$\begin{array}{c}\% \\
\left.\text { Renaturation [ }{ }^{3} \mathrm{H}\right] \mathrm{dsRNA} \\
\text { in Absence of dsRNA } \\
\text { from Other Tissue }\end{array}$} & \multirow[b]{2}{*}{$\begin{array}{l}\% \text { Similarity } \\
\text { of Hairpins }\end{array}$} \\
\hline & & $\begin{array}{c}\text { Total } \\
{ }^{3} \mathrm{H} \text { cpm }\end{array}$ & $\begin{array}{c}\text { RNase-stable } \\
{ }^{3} \mathrm{H} \text { cpm }\end{array}$ & $\begin{array}{c}\% \\
\text { Renaturation }\end{array}$ & low $\mathrm{C}_{\mathbf{0}} \mathrm{t}^{\mathrm{a}}$ & high $\mathrm{C}_{0} \mathbf{t}^{\mathrm{b}}$ & \\
\hline $\begin{array}{c}\text { Krebs carcinoma } \\
\qquad 7 \times 10^{-5}\end{array}$ & $\begin{array}{l}\text { Ehrlich } \\
\text { carcinoma } \\
\quad 4.3 \times 10^{-3}\end{array}$ & $\begin{array}{l}3080 \\
3080\end{array}$ & $\begin{array}{l}340 \\
330\end{array}$ & $\begin{array}{l}11.0 \\
10.7\end{array}$ & 1 & 25 & 40 \\
\hline $\begin{array}{l}\text { Mouse liver } \\
\qquad 8 \times 10^{-5}\end{array}$ & $\begin{array}{l}\text { Ehrlich } \\
\text { carcinoma } \\
\quad 4.3 \times 10^{-3}\end{array}$ & $\begin{array}{l}1940 \\
1940\end{array}$ & $\begin{array}{l}300 \\
240\end{array}$ & $\begin{array}{l}15.5 \\
12.6\end{array}$ & 0 & 35 & 40 \\
\hline $\begin{array}{l}\text { Krebs carcinoma } \\
\qquad 9 \times 10^{-5}\end{array}$ & $\begin{array}{l}\text { Mouse liver } \\
1.7 \times 10^{-3}\end{array}$ & 2400 & 480 & 20.0 & 3 & 19 & 90 \\
\hline
\end{tabular}

a Low $\mathrm{C}_{0} \mathrm{t}=7-9 \times 10^{-5}$ and $b$ high $\mathrm{C}_{0} \mathrm{t}=1.7-4.3 \times 10^{-3}$, as indicated in the first and second columns.

c The calculation was as follows: (renaturation in mixture - renaturation at low $\left.\mathrm{C}_{0} t\right) \times 100 /$ renaturation at high $\mathrm{C}_{0} t$.

Only very rapidly associating fraction was analyzed (see Fig. 4): Highly labeled ${ }^{3} \mathrm{H}$-denatured dsRNA isolated from premRNA of different tissues was mixed with low-labeled, ${ }^{14} \mathrm{C}$-denatured dsRNA from other tissues. The renaturation was carried out as described in Figure 4. In two control experiments, highly labeled hairpins were renatured alone. In one of them, $\mathrm{C}_{0} \mathrm{t}$ was the same as for ${ }^{3} \mathrm{H}$ hairpins in mixture and in another, as for ${ }^{14} \mathrm{C}$ hairpins in vitro. All figures presented are with background (RNase-stable material at $\mathrm{C}_{0} \mathrm{t}=0$ ) subtracted. It comprises $2-5 \%$ in different cases.

Table 4. Hybridization of Long Hairpins with pre-mRNA and mRNA of Krebs Carcinoma Cells

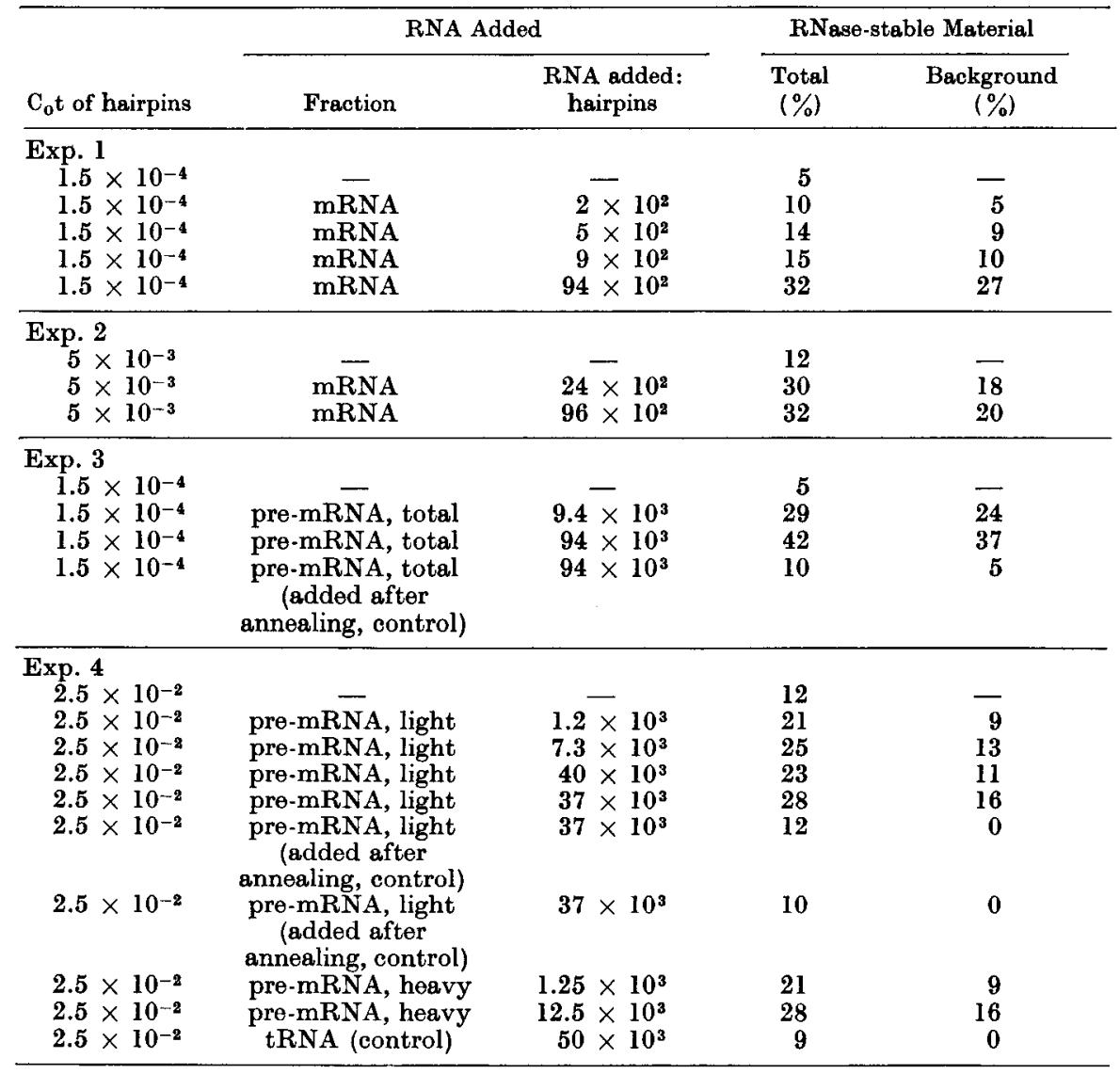

Pre-mRNA of Krebs carcinoma cells was isolated by hot phenol fractionation (Georgiev et al., 1972) and separated into fractions with different $S$ values. mRNA was isolated ac. cording to Lee et al. (1971) from the same cells. Long dsRNA sequences were prepared from ${ }^{3} \mathrm{H}$-labeled, heavy pre-mRNA as described in Figure 2 . They were melted by heating and then reannealed (see Fig. 4) alone or with mRNA or pre-mRNA added in excess. mRNA and pre-mRNA were not preheated to avoid melting of double-stranded regions. RNase treatment and counting of RNase-stable material were as described in the legend to Figure 4. 


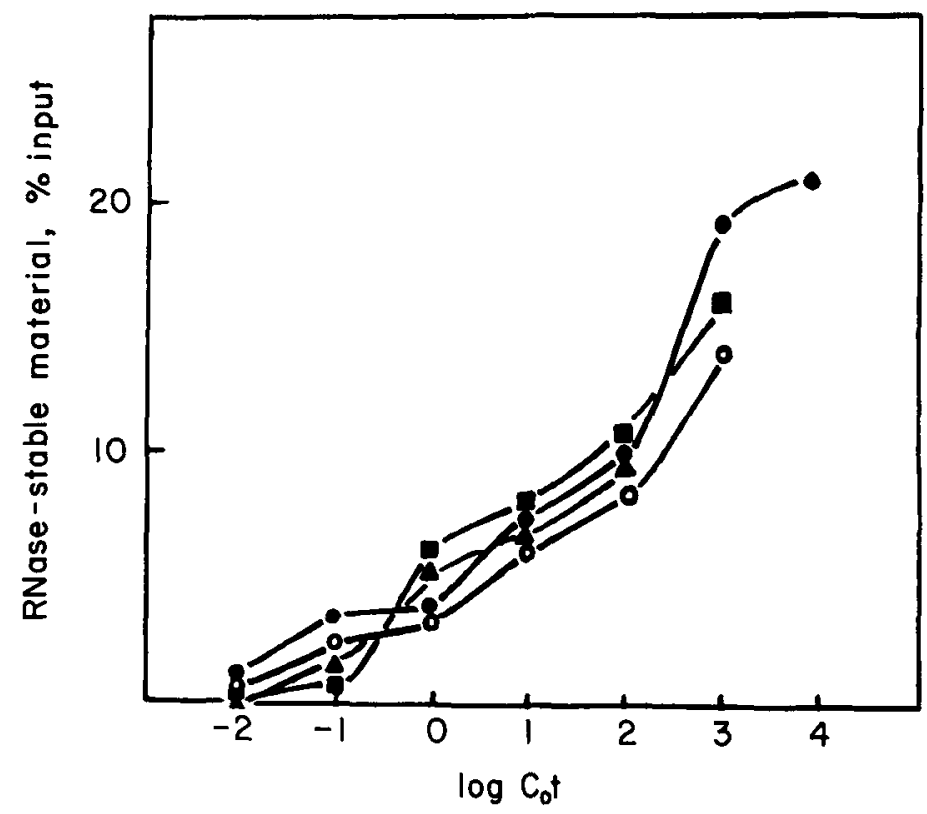

Figure 5. Self-annealing of premRNA fractions. Pre-mRNA was isolated from Ehrlich ascites carcinoma cells with the aid of hot phenol fractionation technique and separated by centrifugation in sucrose gradient. The fractions were collected, purified additionally by DNase and hot phenol treatment, dissolved in $0.01 \times \mathrm{SSC}$, heated $5 \mathrm{~min}$ at $95^{\circ} \mathrm{C}$, made $2 \times \mathrm{SSC}$, and annealed for the required time. The total activity was measured in one aliquot; RNase mixture was then added to another aliquot and incu. bated during $30 \mathrm{~min}$. RNase-resistant material was precipitated by $5 \%$ TCA in the presence of carrier RNA. The amount of RNase-resistant material was determined. The amount of RNase stable material just after melting was about $2-5 \%$ for different RNA samples, and this background was subtracted from all figures. (- - Pre-mRNA of Ehrlich ascites carcinoma cells obtained in temperature interval 55$65^{\circ} \mathrm{C}(10-30 \mathrm{~S}$ fraction); (一匹一) the same, but obtained in temperature in. terval $65-85^{\circ} \mathrm{C} \quad(10-30 \mathrm{~S}$ fraction); $(-\mathbf{A}-)$ the same, but heavy fraction, 40-80 $\mathrm{S} ;$ ( - O - ) pre-mRNA of mouse liver obtained in interval $65-85^{\circ} \mathrm{C}(40$ $80 \mathrm{~S}$ fraction).

(4) Typical for pseudo-mRNA are hairpin-like structures which are transcripts from reverted repetitions in DNA. They may be divided into long and short hairpins. Among long hairpins one could find sequences of different degrees of reiteration. A part of hairpin sequences are complementary to nonpaired reiterated sequences of pre-mRNA and mRNA.

The role of the specific sequences in pre-mRNA is still to be established.

\section{Arrangement of Histones along Unfolded Chromosomal DNA}

The second level of chromatin structure is the arrangement of protein in linearized (unfolded) deoxyribonucleoprotein (DNP). DNA in chromatin is combined with histones and nonhistone proteins and folded in some unknown way. Linearization of chromosomal DNP may be achieved by treatment with urea (Georgiev et al., 1970) or by extraction with $0.6 \mathrm{M} \mathrm{NaCl}$, which removes histone F1 (Georgiev et al., 1967; Ohlenbusch et al., 1967). However, both techniques induce redistribution of proteins which remain bound to DNA (Ilyin et al., 1971; Varshavsky, Ilyin, and Georgiev, 1973). Recently milder techniques were described which are based on the transfer of some histones from DNP to added free tRNA or DNA. In the presence of EDTA, three histones, namely, F1, F2a2, and F2b, together with most nonhistone proteins, are transferred -in the presence of $\mathrm{Mg}^{2+}$ ions only $\mathrm{Fl}$ and most of the nonhistone proteins are removed from chromatin (Ilyin et al., 1971; Varshavsky and Georgiev, 1972). The DNP preparation lacking three histones was used in studies on histone arrangement along DNA (Varshavsky and Georgiev, 1972). Long ( $\sim 1 \times 10^{3}$ base pairs) stretches of free DNA were found, but even in this case, as will be shown below, some redistribution of remaining histones takes place.

For this reason, the experiments described below were carried out with the DNP lacking only one histone $(F 1)-\left(D_{-F 1}\right)$. The transfer of histone FI and of nonhistone proteins from the chromatin to the tDNA in the presence of $\mathrm{Mg}^{2+}$ results in the lowest, if any, redistribution of other histones.

To analyze histone arrangement along DNA, equilibrium centrifugation of formaldehyde-fixed DNP in CsCl density gradient was used (Ilyin and Georgiev, 1969; Ilyin et al., 1970). The buoyant density of DNA is $1.70 \mathrm{~g} / \mathrm{cm}^{3}$ and of protein, 1.25$1.3 \mathrm{~g} / \mathrm{cm}^{3}$. Therefore, the buoyant density is a function of the protein content of the DNP molecule. Investigation of density patterns of DNP preparations sheared to various lengths of DNA gives information on protein arrangement in the unfolded ("linearized") DNP.

In agreement with previous data (Ilyin et al., 1970; Hancock, 1970), initial untreated chromatin, solubilized by extensive shearing, gives in $\mathrm{CsCl}$ density gradient one broad peak with mean density of about $1.41 \mathrm{~g} / \mathrm{cm}^{3}$ (Fig. 6). No free DNA was found, although of course this applies only to the DNP fragments containing DNA chains of about 
500 base pairs. The existence of shorter blocks of free DNA, as described by Clark and Felsenfeld (1971) and Itzhaki (1971), is not excluded by these experiments. After the removal of histone F1 and of most nonhistone proteins by treatment with

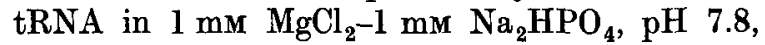
it is also possible to work with almost unsheared DNP samples. Such a DNP -Fi $_{1}$ preparation, containing DNP molecules with average length of $\sim 10 \times 10^{3}$ base pairs, gives a sharp peak in $\mathrm{CsCl}$ at a density of $1.46 \mathrm{~g} / \mathrm{cm}^{3}$, and also a significant amount of material is present in the region of higher densities, almost up to the density of free DNA (Fig. 7A). Even after moderate shearing produces rather long chains $\left(\sim 4 \times 10^{3}\right.$ base pairs on average), the second peak already appears with density equal to $1.70 \mathrm{~g} / \mathrm{cm}^{3}$, i.e., the peak of free DNA (Fig. 7B). At an average chain length of about 500 base pairs (extensive shearing) the
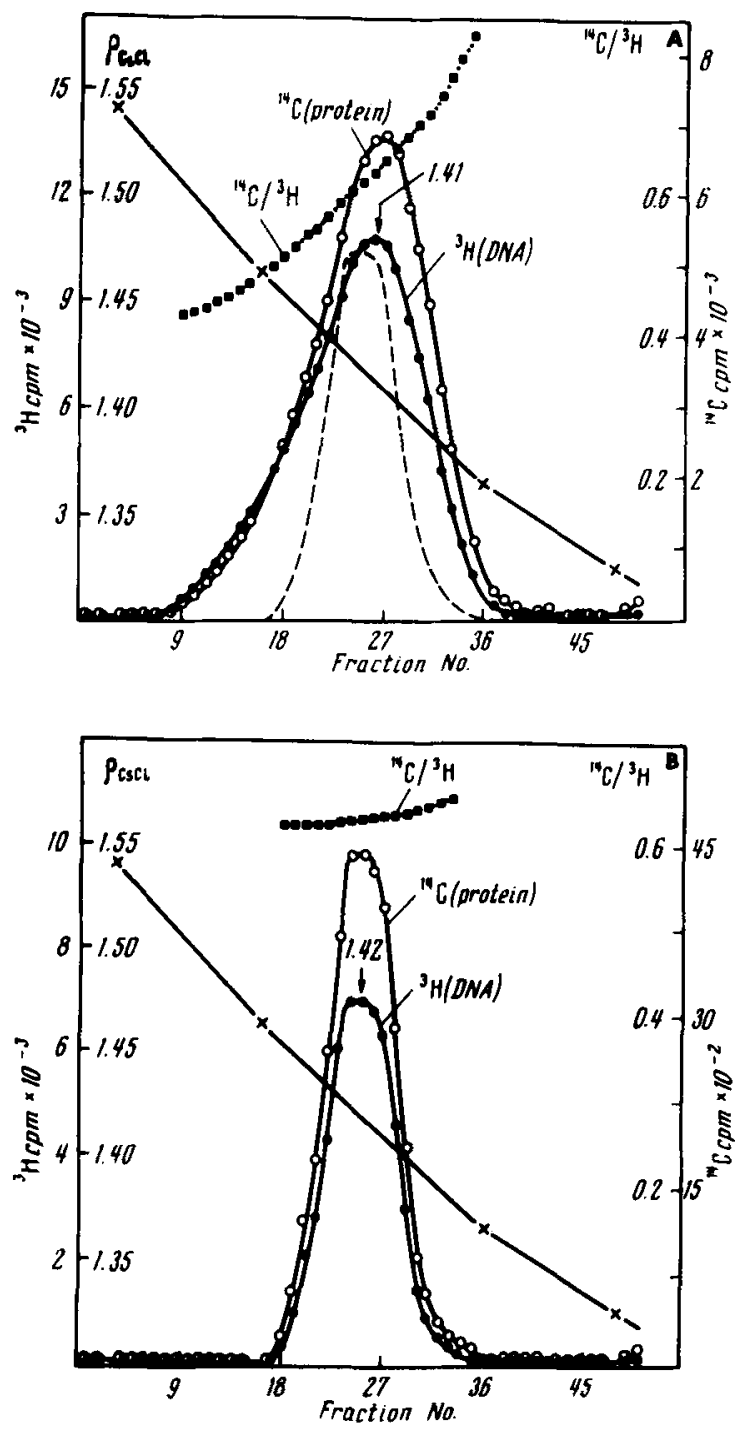

intermediate material between two peaks disappears almost completely and only two sharp peaks are present with densities of 1.70 and 1.46 $\mathrm{g} / \mathrm{cm}^{3}$ (Fig. 7C, D). The amount of DNA recovered as free DNA is about $20 \%$ of the total. It should be noted that in the double-labeled DNP preparation $\left(\left[{ }^{3} \mathrm{H}\right] \mathrm{DNA} ;{ }^{14} \mathrm{C}\right.$-protein) no protein is recovered in the peak of free DNA. On the other hand, the protein to DNA ratio in all fractions of the peak "1.46" (Fig. 7A-D) is exactly the same; i.e., this material is almost completely homogeneous.

Calculations based on the dependence of density patterns on DNA chain length give average sizes for free DNA and DNP covered with four histones of about $4 \times 10^{3}$ and $16 \times 10^{3}$ base pairs, respectively.

Some control experiments were carried out to check the possibility of redistribution of proteins during removal of histone Fl and DNP unfolding. In the first experiment the chromatin was extensively sheared before addition of tRNA. Then $\mathrm{DNP}_{-\mathrm{F} 1}$ was obtained and analyzed (Fig. 8A). The density pattern was similar to that in the case of DNP $_{-\mathrm{F} 1}$ sheared after tRNA treatment.

Thus the appearance of free DNA after the removal of histone $\mathrm{Fl}$ is apparently not due to sliding of the remaining histones along DNA. At the same time, the protein exchange between different DNP molecules in the above conditions was also excluded (Ilyin et al., 1971). For this reason, the observed pattern of protein arrangement along DNA seems not to be a result of histone redistribution.

Figure 6. $\mathrm{CsCl}$ equilibrium patterns of DNP preparations containing full complement of histones. $(A) \mathrm{DNP}_{0}$ : Mice carrying Ehrlich ascites carcinoma cells were labeled simultaneously with $\left[\mathrm{Me}^{3}{ }^{3} \mathrm{H}\right]$ thymidine and $\mathrm{L} \cdot\left[{ }^{14} \mathrm{C}\right] \mathrm{lysine}$ by six intraperitoneal injections on the fourth and fifth days after inoculation with tumor cells. On the seventh day the cells were collected. Chromatin was isolated as described by Ilyin et al. (1971), washed with $0.3 \mathrm{M} \mathrm{NaCl}$, 0.01 м Tris-HCl, $\mathrm{pH} \mathrm{7.8,} \mathrm{then} \mathrm{with} 1 \mathrm{mM}$ triethanolamine$\mathrm{HCl}, \mathrm{pH} 7.8$, suspended in this solution to a concentration of $40-100 \mu \mathrm{g} / \mathrm{ml}$ and then passed through the special press to reduce average length of DNA to $\sim 1 \times 10^{3}$ base pairs. The sample was centrifuged at $10,000 \mathrm{~g}$ for $30 \mathrm{~min}$ (more than $95 \%$ of ${ }^{3} \mathrm{H}$ and $90-95 \%$ of ${ }^{14} \mathrm{C}$ remained in supernatant), fixed with $2 \% \mathrm{CH}_{2} \mathrm{O}$ (Varshavsky and Georgiev, 1972), and then centrifuged to equilibrium in the fixed-engle Ti50 rotor at $46,000 \mathrm{rpm}$ for $70-75 \mathrm{hr}$ at $10^{\circ} \mathrm{C}$. Fractions were collected directly onto glass filters, which were dried, washed with $7 \%$ TCA and ethanol, dried again, and counted with toluene-PPO-POPOP in the computerized SL-40 Counter (Intertechnique). (-X - ) Density; $(---)$ equilibrium pattern of DNP treated $^{-}$ with $4 \mathrm{~m}$ urea before fixation. $(B) \mathrm{DNP}_{0}$ treated with urea: Chromatin was suspended in $1 \mathrm{mM}$ Tris- $\mathrm{HCl}, \mathrm{pH} \mathrm{7.8,} \mathrm{and}$ then mixed with two volumes of $6 \mathrm{M}$ deionized urea, $1 \mathrm{mM}$ Tris-HCl, pH 7.8. The solubilized DNP was sheared to an average length of about $1 \times 10^{3}$ pairs, then dialyzed against several changes of $1 \mathrm{~mm}$ triethanolamine- $\mathrm{HCl}, \mathrm{pH}$ 7.8, fixed with $\mathrm{CH}_{2} \mathrm{O}$ and centrifuged to equilibrium as described above. 

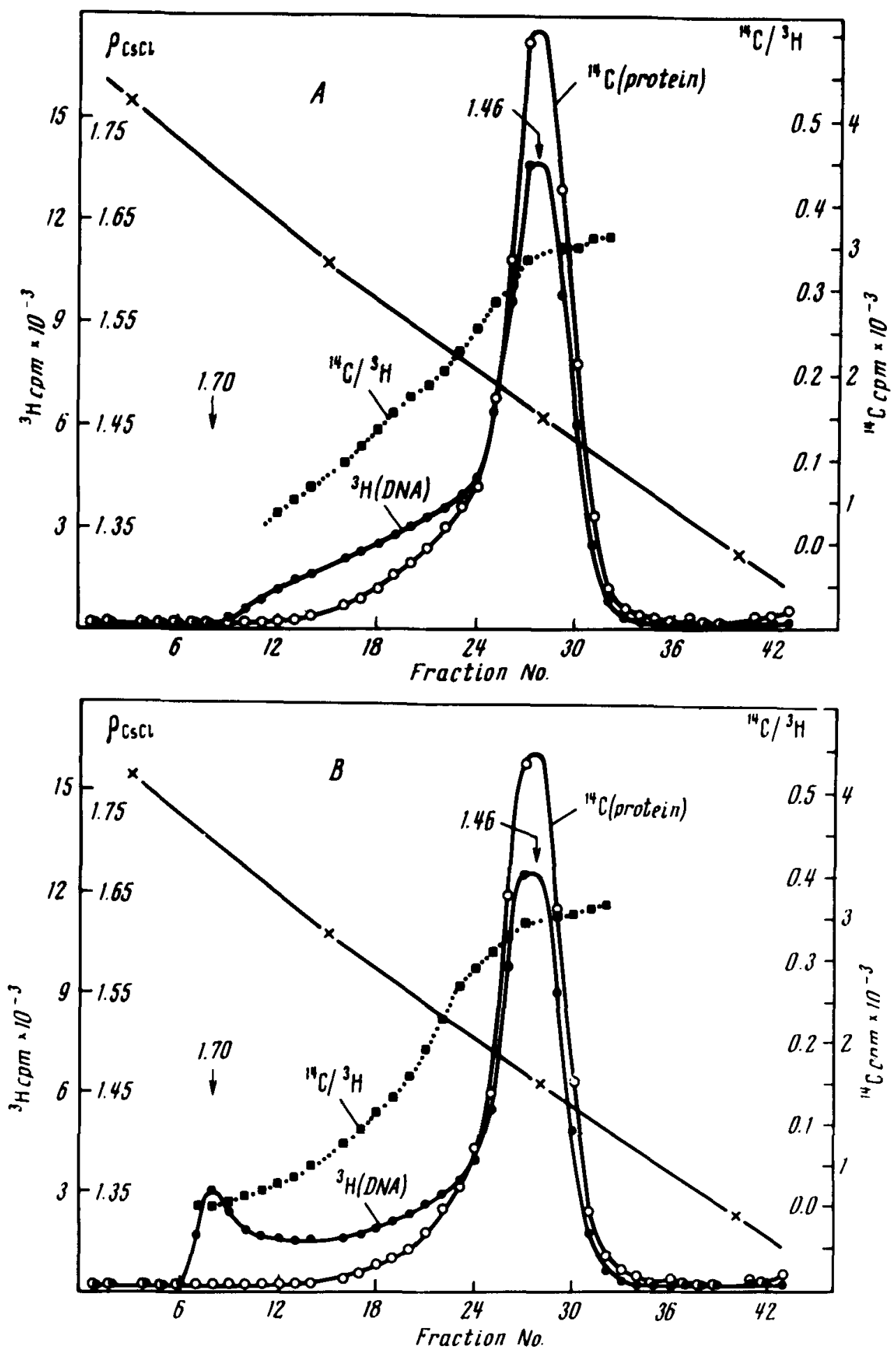

Figure 7. Arrangement of histones in DNP $-F_{1} .{ }^{3} \mathrm{H},{ }^{14} \mathrm{C}$-chromatin, obtained as described in Figure $6 \mathrm{~A}$, was washed and suspended in $1 \mathrm{mM} \mathrm{MgCl}, 1 \mathrm{mM} \mathrm{Na} \mathrm{HPO}_{4}, \mathrm{pH} 7.8$. The purified yeast tRNA was added to a concentration of $1 \mathrm{mg} / \mathrm{ml}$ and the mixture was incubated with slow shaking for $4-5 \mathrm{hr}$ at $0^{\circ} \mathrm{C}$. The swelled gel was solubilized by several strokes in a Dounce homogenizer. DNP $-F 1$ was separated from free tRNA and from tRNA.protein complexes by gel chromatography on Biogel A-25m. It was fixed in $2 \% \mathrm{CH}_{2} \mathrm{O}, \mathrm{pH} 7.8$, for $20-80 \mathrm{hr}$ at $4^{\circ} \mathrm{C}$, followed by dialysis against $1 \mathrm{~mm} \mathrm{Na-EDTA}, 1 \mathrm{mM}$ $\mathrm{Na}_{2} \mathrm{HPO}_{4}$, $\mathrm{pH}$ 7.8. Fixed DNP was sheared (by treatment in a Dounce homogenizer, by sonication, or by passing through a press) to a required average length of DNA (the molecular weight of DNA was determined by sucrose gradient centrifugation of DNA in the presence of internal sedimentation markers). The samples of DNP-F1 were mixed with $\mathrm{CsCl}$ and centrifuged at $46,000 \mathrm{rpm}$ for $70-75 \mathrm{hr}$ at $10^{\circ} \mathrm{C}$ in the $\mathrm{SW} 50$ rotor. The gradient was analyzed as described in Figure 6. $D_{-F 1}$ sheared to an average length of $(A) \sim 10 \times 10^{3}$ base pairs; $(B) \sim 4 \times 10^{3}$ base pairs; $(C) \sim 1.2 \times 10^{3}$ base pairs; (D) $\sim 5 \times 10^{2}$ base pairs. $(-\mathrm{x}-$ ) Density. 

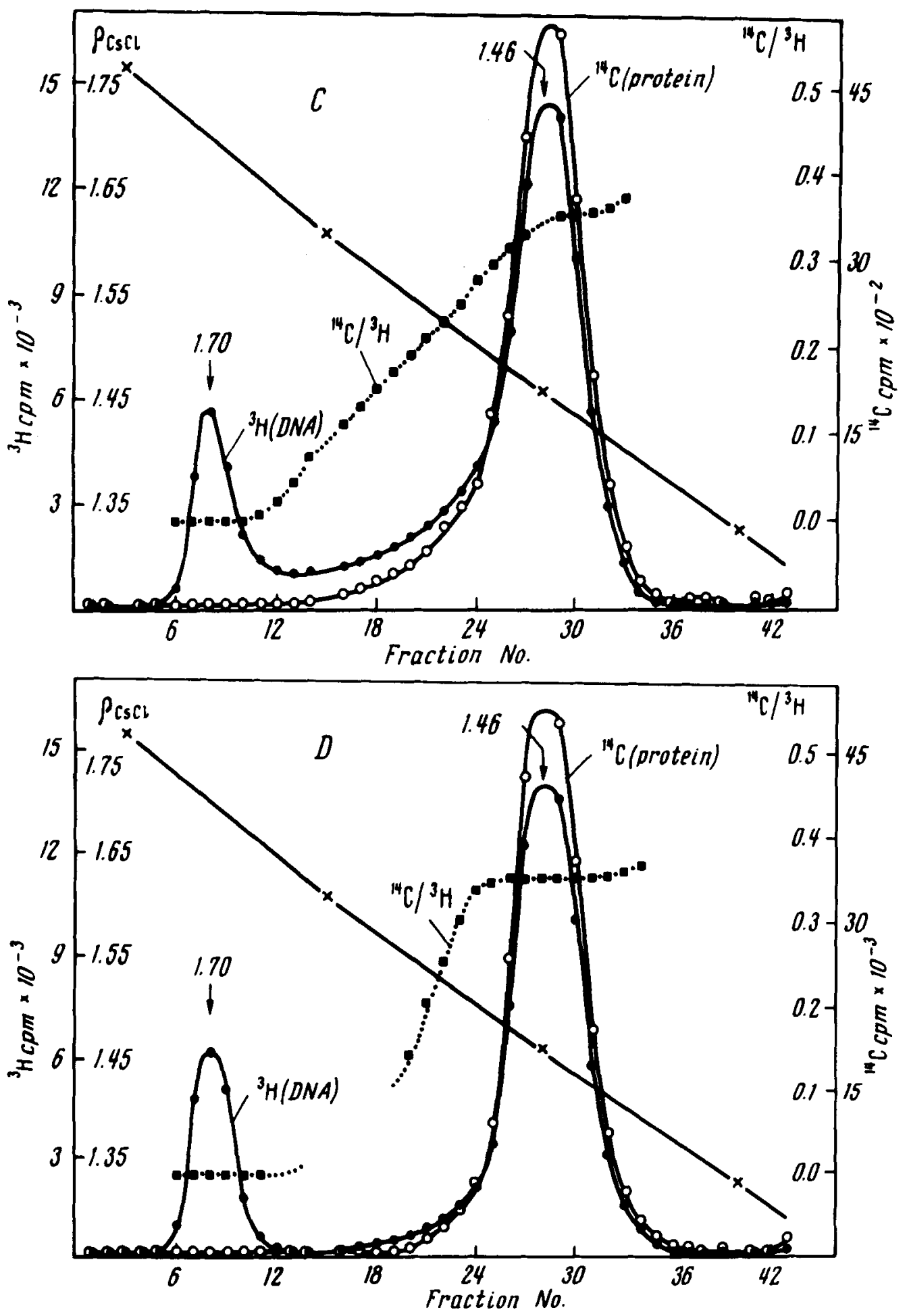

Figure 7 (continued). 


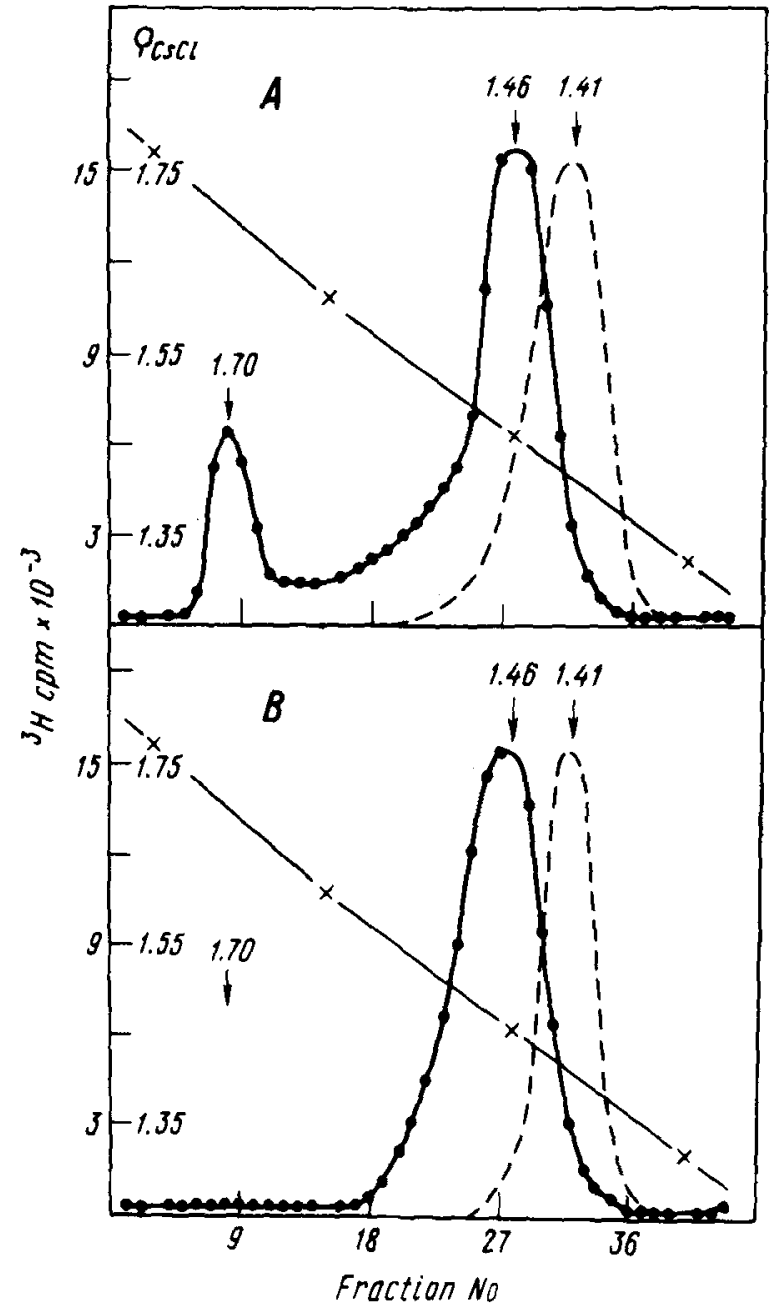

Figure 8. The results of some control experiments. $(A)$ Fragmentation of the chromatin before removal of histone Fl. Soluble DNP o was obtained as described in Figure $6 \mathrm{~A}$ and then made $1 \mathrm{mM} \mathrm{MgCl}_{2}, 1 \mathrm{mM} \mathrm{Na} \mathrm{NaO}_{4}$, pH 7.8. tRNA was then added to $1 \mathrm{mg} / \mathrm{ml}$. The mixture was incubated, then fixed with $\mathrm{CH}_{2} \mathrm{O}$ and analyzed in $\mathrm{CsCl}$ density gradient. In separate experiments it was shown that the presence of tRNA and tRNA.protein in the mixture does not interfere with fixation and equilibrium centrifugation distribution of DNP. (B) Influence of protein redistribution on the length of histone-free DNA. Soluble DNP o was treated with $4 \mathrm{M}$ urea (see Fig. 6B) with subsequent removal of urea by dialysis against $1 \mathrm{~mm}$ $\mathrm{MgCl}_{2}-1 \mathrm{mM} \mathrm{Na} \mathrm{HPO}_{4}, \mathrm{pH} 7.8$. tRNA was then added to a concentration of $1 \mathrm{mg} / \mathrm{ml}$, and the material was treated as described in $(A)$. (O) $\left.{ }^{3} \mathrm{H}\right] \mathrm{DNA} ;(--)$ indicates the equilibrium patterns of $\mathrm{DNP}_{0}$ in $(A)$ and $\mathrm{DNP}_{0}$ treated with urea in $(B)$.

Another control was to explore the influence of artificially induced protein redistribution on the density pattern of the $\mathrm{DNP}_{-\mathrm{F} 1}$. Urea treatment of the chromatin is known to induce protein redistribution, as can be seen from Figure $6 \mathrm{~B}$ where the $\mathrm{CsCl}$ pattern of DNP treated with urea is clearly different from those of original $\mathrm{DNP}_{a}$. Such urea-treated DNP was dialyzed to remove urea and then mixed with tRNA in $1 \mathrm{mM} \mathrm{MgCl}_{2}-\mathrm{ImM} \mathrm{Na}_{2} \mathrm{HPO}_{4}, \mathrm{pH}$ 7.8. No free DNA was now observed, even after extensive shearing of the fixed DNP samples (Fig. $8 \mathrm{~B})$. Thus the redistribution of proteins leads to the randomization of DNP composition and to the disappearance of long protein-free DNA segments.

It is important that the size of the pair-one segment of free DNA plus one segment of histonecovered DNA-is very large (about $3 \times 10^{6}+$ $12 \times 10^{6}=15 \times 10^{6}$ daltons), and thus comparable with the size of the average transcripton. We suggest that each transcripton consists usually of one or sometimes of a few such structural pairs.

If there is any relation between structural units in DNP and functional genetic elements, one could

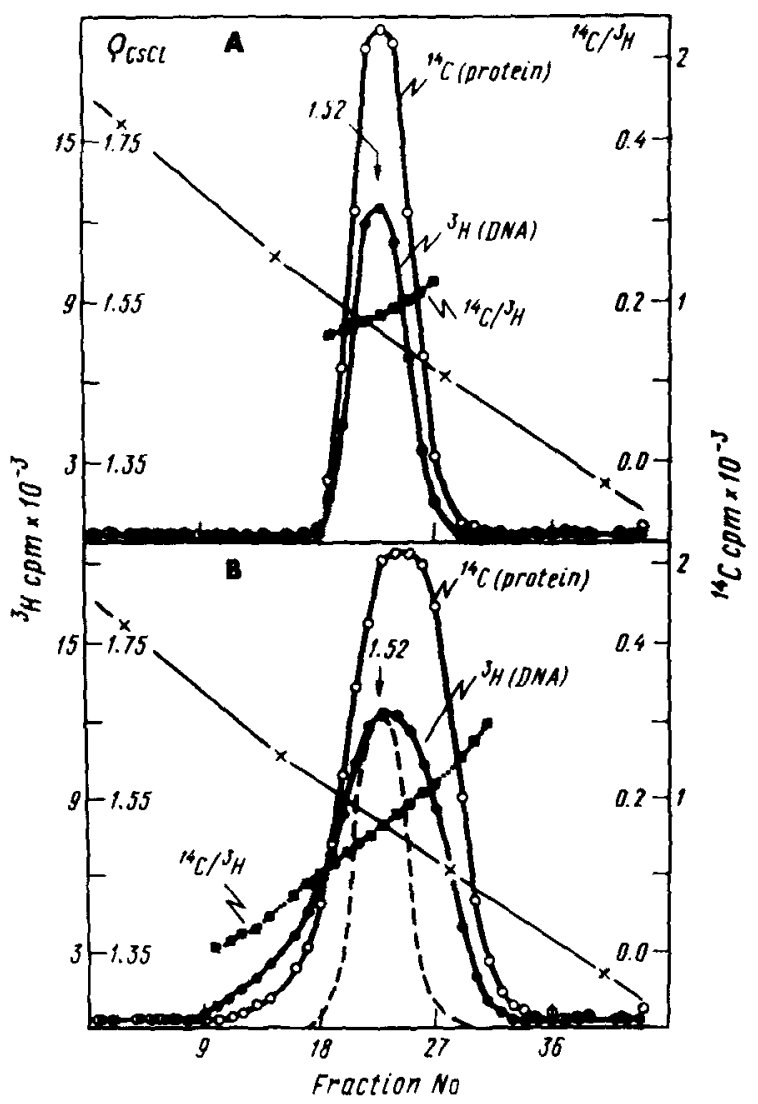

Figure 9. Equilibrium centrifugation of DNA. $(\mathrm{F} 2 \mathrm{al}+\mathrm{F} 3)$ in $\mathrm{CsCl}$ density gradient. ${ }^{3} \mathrm{H},{ }^{14} \mathrm{C}$-chromatin was dissolved in $2 \mathrm{M}$ urea, $5 \mathrm{~mm}$ Tris-HCl, $\mathrm{pH} 7.8$ (see Fig. 6B) (DNA concentration, $40-100 \mu \mathrm{g} / \mathrm{ml}$ ), sheared in a Dounce homogenizer, mixed with extensively sheared unlabeled, double-stranded mouse DNA ( $\sim 5 \times 10^{2}$ base pairs long) to a final concentration of $1.2 \mathrm{mg} / \mathrm{ml}$ and incubated at $0^{\circ} \mathrm{C}$ for about $5 \mathrm{hr}$. DNP was separated from complexes of proteins with sheared DNA and from free DNA by sucrose gradient centrifugation, dialyzed, fixed, and centrifuged to equilibrium in a $\mathrm{CsCl}$ density gradient $\left(70-75 \mathrm{hr}\right.$ at $10^{\circ} \mathrm{C}$ in the $\$$ W50 rotor). (A) DNA.(F2al + F3); average length of DNA is $\sim 10 \times 10^{3}$ base pairs. $(B)$ The same, but sheared after fixation to a length of $\sim 5 \times 10^{3}$ base pairs. (-x-) Density; $(---)$ indicates the $\mathrm{CsCl}$ patterns of $(A)$. 
expect that the base sequences, at least the nonrepetitious ("unique") base sequences, are different in free and histone-covered DNA. On the other hand, if the formation of free and covered stretches is a purely in vitro phenomenon, accompanying DNP unfolding, both fractions should be random and contain all types of base sequences. To check this one should compare the kinetics of reassociation of the total mouse DNA and of the free DNA which was obtained from the $\mathrm{DNP}_{-\mathrm{F} 1}$.

These experiments are in progress now.

\section{Folding of DNP in Chromatin}

The mode of DNA packing in chromatin fibrils remains unclear. The possibilities of superhelical configuration (Pardon and Wilkins, 1972) or doubledouble helix (Crick, 1971) were considered. We have no direct evidence bearing on the structure of folded DNP, but some data obtained in the course of studies on histone arrangement along DNA and on the pattern of histone redistribution in the chromatin make it possible to suggest some schematic models.

The experimental result is the discovery of dependence of the length of free DNA on the conditions of DNP unfolding which is induced by treatment with tRNA. It is known from previous studies (Ilyin et al., 1971; Varshavsky and Georgiev, 1972) that in preparations of unfolded DNP the transfer of the arginine-rich histones (F2al and F3) to added free acceptors (DNA or tRNA) as well as sliding of histones along the DNA strand do not take place (see also above). At the same time, moderately lysine-rich histones $\mathrm{F} 2 \mathrm{a} 2$ and $\mathrm{F} 2 \mathrm{~b}$ are transferred from the DNP to added free DNA (Ilyin et al.,
1971; Varshavsky and Ilyin, unpublished), but this process is very slow and does not interfere with the appearance of free DNA stretches. Thus one could expect that if histones $\mathrm{F} 1, \mathrm{~F} 2 \mathrm{a} 2$, and $\mathrm{F} 2 \mathrm{~b}$ are transferred from chromatin to added free tRNA, the average length of free DNA stretches should be at least the same as after removal of histone Fl only. However this is not the case.

Previously we have found that in DNP containing only histones F2al and F3, designated as DNA. (F2a1 + F3), which was obtained by tRNA treatment in the presence of $1 \mathrm{~mm} \mathrm{Na-EDTA,} \mathrm{pH} \mathrm{7.8,}$ the average length of free DNA stretches is equal to $900-1000$ base pairs (Varshavsky and Georgiev, 1972). This is at least four times less than in the $\mathrm{DNP}_{-\mathrm{F} 1}$, although the latter DNP preparation is characterized by much higher protein/DNA ratio than the former.

The preparation of DNA. F2a1 + F3) may be obtained also in another way, namely by treatment of chromatin with excess of sheared doublestranded free DNA in the presence of $2 \mathrm{~m}$ urea. In the unfolded DNP, urea does not induce redistribution of the two arginine-rich histones (Ilyin et al., 1971). However, even after extensive shearing of such DNA.(F2al + F3) preparations, no free DNA at all could be detected in $\mathrm{CsCl}$ density gradient (Fig. 9).

The explanation of these results is that justat the moment of histone transfer from DNP to added tRNA or DNA, accompanied by unfolding of DNA, some part of the histones are shifted from a stretch covered by histones to a free DNA stretch. In the absence of urea, this previously unrecognized type of transfer is completely inhibited by addition of a

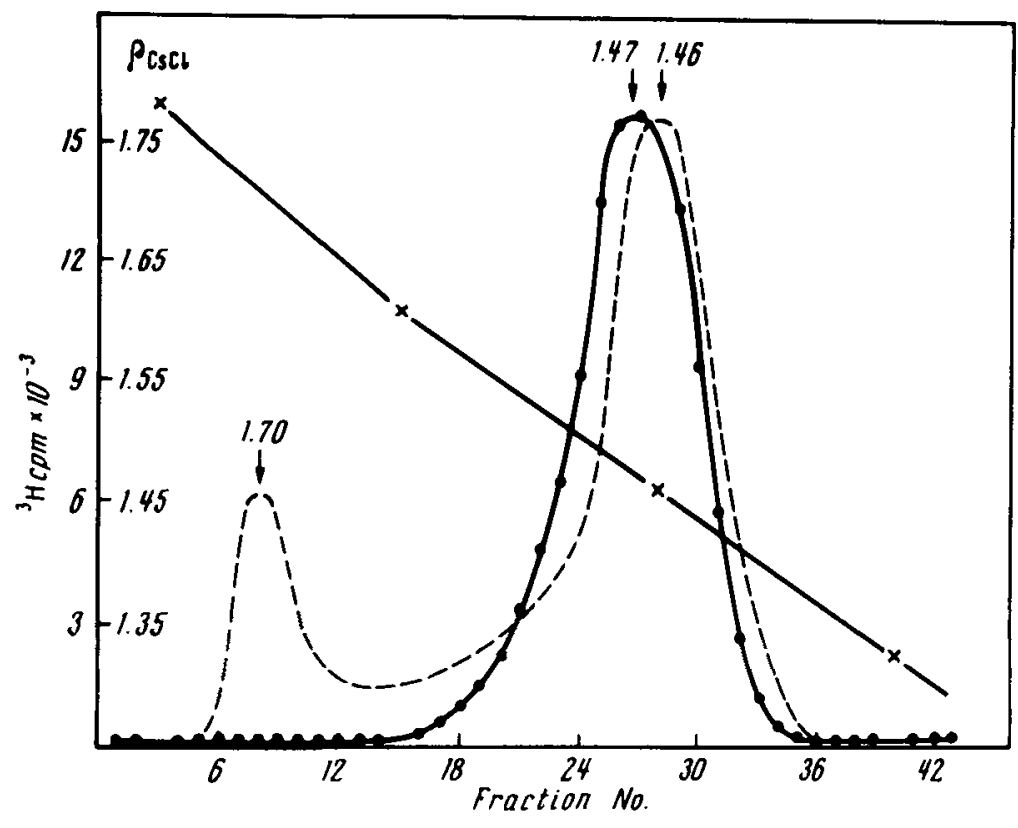

Figure 10. $\mathrm{CsCl}$ pattern of sheared chromatin treated with tRNA in the presence of EDTA. Soluble DNP was obtained by hydrodynamic shearing in $1 \mathrm{~mm}$ triethanolamine- $\mathrm{HCl}, \mathrm{pH}$ 7.8. It was adjusted to $1 \mathrm{mM}$ EDTA, $\mathrm{pH} 7.8$, and tRNA was then added to a final concentration of $1 \mathrm{mg} / \mathrm{ml}$. The subsequent treatment is as described in legend to Figure 9A. (o) $\left[{ }^{3} \mathrm{H}\right] \mathrm{DNA}$; $(-\mathbf{x}-)$ density; (- --$)$ indicates the equilibrium pattern of the DNP ${ }_{-F_{1}}$ ob. tained from the sheared chromatin in the presence of $1 \mathrm{mM} \mathrm{MgCl}_{2}$ (Fig. $8 \mathrm{~A}$ ). 


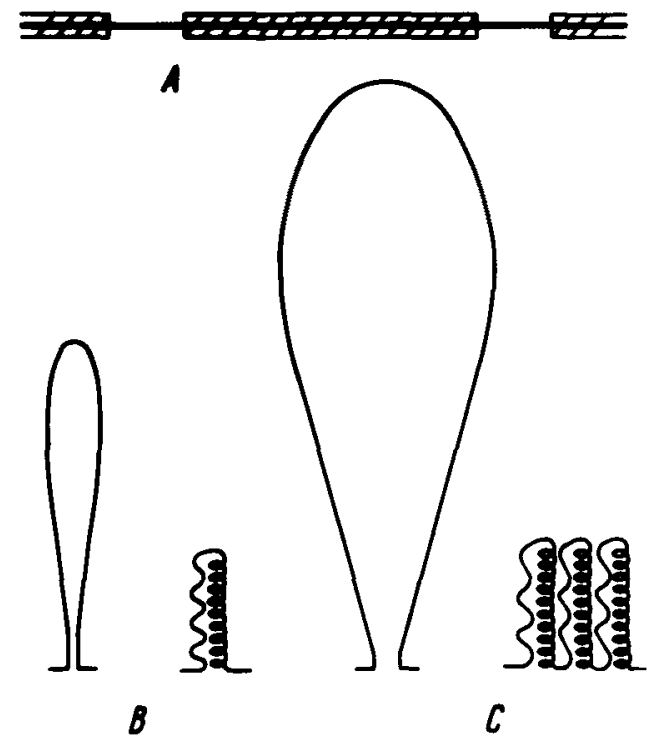

Figure 11. A model of DNA packing in chromatin. $(A)$ arrangement of four histones (other than histone Fl) along unfolded chromosomal DNA; $(B)$ a highly schematic drawing of the mode of DNA packing in a "small" chromomere; $(C)$ a mode of DNA packing in a "large" chromomere. The entire "hairpin" may be additionally folded on itself resulting in a decrease in asymmetry of the whole structure.

sufficient amount of magnesium ions. If $\mathrm{MgCl}_{2}$ is added, but its concentration is slightly lower than optimal, the length of free DNA in $\mathrm{DNP}_{-\mathrm{F} 1}$ obtained becomes $2-3$ times shorter (data not shown).

It should be noted that the same phenomenon is observed if the transfer of histone Fl to tRNA is carried out with the same sheared chromatin sample that gave a lot of free DNA after removal of histone Fl by tRNA in the presence of $\mathrm{Mg}^{2+}$ (Fig. 8A). No free DNA was found if the removal of Fl was carried out in the presence of $1 \mathrm{~mm} \mathrm{Na-}$ EDTA (Fig. 10).

We suggest that the transfer of histones other than histone F1 in the course of DNP unfolding depends of the following structural organization of chromatin. Segments of DNA covered with four histones and segments of DNA free from them are brought close together in space, thereby forming two "branches" of a hairpin-like structure (Fig. 11). The branch covered with four histones is packed about four times more tightly than the other branch. It may be supercoiled for example. Histone F1 is responsible for the integrity of the whole structure, combining with either free DNA branch or with both branches of a double "hairpin." One or a few such structural units form one transcripton. The activation of the transcripton by binding of specific factors (e.g., nonhistone proteins) or by removal or modification of histone Fl leads to the unfolding of a "hairpin." The postulated DNP hairpin should be rather asymmetric, and its average length should be of about $1 \mu$. One can suggest that the entire "hairpin" is additionally folded on itself forming a compact chromomere. During the extensive hydrodynamic shearing of the chromatin gel, the long hairpin may be cut to shorter fragments which behave in the same way as the original long structure upon tRNA treatment with or without $\mathrm{Mg}^{2+}$ (see above). For final conclusions special structural studies, including X-ray diffraction studies, are necessary.

One of the important questions that remains is the relationship between the three levels of chromosome organization mentioned above, and this question is now being investigated.

\section{Acknowledgments}

The authors are deeply indebted to M. Eugenev, D. Kramerov, G. Baiszar, V. Farashyan, and S. Limborska for their collaboration in some of the above-mentioned experiments, and to $\mathrm{N}$. $\mathrm{N}$. Dobbert for technical assistance.

\section{Note Added in Proof}

Recent findings (Varshavsky et al., 1974) confirm and extend the experimental data described above. It was shown that hydrodynamic shearing of chromatin in the presence of $\mathrm{Mg}^{2+}$ ions (0.6-1.0 $\mathrm{mM} \mathrm{MgCl}_{2}$ ) produces two discrete types of particles: (a) molecules of completely free DNA which constitute $20-25 \%$ of the total nuclear DNA and (b) deoxyribonucleoprotein (DNP) particles which contain all five histone fractions. The average length of free DNA molecules depends on the intensity of shearing and can be as high as 1000 base pairs or more.

Shearing of chromatin in the absence of $\mathrm{Mg}^{2+}$ ions produces a heterogeneous population of DNP particles; no free DNA is liberated. However, the addition of $\mathrm{MgCl}_{2}(0.6-1.0 \mathrm{mM})$ or of $\mathrm{NaCl}(0.15 \mathrm{M})$ to such a DNP preparation results in the appearance of free DNA molecules and in a complete restoration of the above "bimodal" distribution.

These findings can be explained in two alternative ways: (1) Each DNP particle in the sheared chromatin (without $\mathrm{Mg}^{2+}$ ) contains two covalently unlinked DNA molecules and thus corresponds to a fragment of the "asymmetric hairpin" (see Fig. 11). Addition of $\mathrm{Mg}^{2+}$ results in separation of the two DNA molecules, one of which becomes completely free whereas the other remains histonecovered. (2) Each DNP particle in the sheared chromatin (without $\mathrm{Mg}^{2+}$ ) contains only one DNA molecule. In the presence of $\mathrm{Mg}^{2+}$ ions interactions between different DNP particles, for example, during "dimer" formation, lead to an "asymmetric" redistribution of proteins between two DNP particles in the dimer. As a result, dissociation of the 
dimer produces one molecule of free DNA and one molecule of DNA associated with increased amount of protein.

\section{References}

Ando, T. 1966. A nuelease specific for heat-denatured DNA isolated from a product of Aspergillis/Oryzae. Biochim. Biophys. Acta 114: 158.

Arion, V. JA. and G. P. Georgiev. 1967. On the functional heterogeneity of chromosomal informational RNA. Proc. Acad. Sci. (USSR) 172: 716.

Beermans, W. 1972. Functional aspects of the chromomeric organization of eukaryotic chromosomes, p. 190. In Cell nucleus: Morphology, physiology, and biochemistry, ed. I. B. Zbarsky and G. P. Georgiev. Nauka, Moscow.

Bishop, J. O. and M. Rosbash. 1973. Reiteration frequency of duck haemoglobin genes. Nature New Biol. 241 : 204 .

Bishop, J. O., R. Pemeerton, and C. Baglioni. 1972. Reiteration frequency of haemoglobin genes in the duck. Nature New Biol. 235: 231.

Burdon, R. H. and A. SHenkin. 1972. Uridylate-rich sequences in rapidly labeled RNA of mammalian cells. $F E B S$ Letters 24: 11.

Clark R. J. and G. Felsenfeld. 1971. Structure of chromatin. Nature New Biol. 229: 101.

Coutelle, C., A. P. Ryskov, and G. P. Georgiev, 1970. Localization of messenger RNA near the $3^{\prime}$-end of dRNA precursor molecule. FEBS Letters 12: 21 .

Crick, F. 1971. General model for the ehromosome of higher organisms. Nature 234: 25

Dariele, J. E., R. WAlL, and R. L. Tushinsky. 1971. An adenylic acid-rieh sequence in messenger RNA of HeLa cells and its possible relationship to reiterated sites in DNA. Proc. Nat. Acad. Sci. 68: 1321.

Edmonds, M., M. N. Vavghan, and H. NaKazoto. 1971. Polyadenylic acid sequences in heterogeneous nuclear RNA and rapidly-labeled polyribosomal RNA of HeLa cells: Possible evidence for a precursor relationship. Proc. Nat. Acad. Sci. 68: 1336.

Georgiev, G. P. 1966. Metabolism of nuclear RNA fractions. In The cell nucleus-metabolism and radiosensitivity, p. 79. Taylor \& Francis, London.

- 1969. On the structural organization of operon and the regulation of RNA synthesis in animal cells. $J$. Theoret. Biol. 25: 473 .

Georgiev, G. P. and V. L. Mantieva. 1962. The isolation of DNA-like RNA and ribosomal RNA from the nucleolo-chromosomal apparatus of mammalian cells. Biochim. Biophys. Acta 61 : 153.

Georgiev, G. P., Yu. V. Ilyin, A. S. Tikhonenko, and V. JA. Stelmaschuk. 1970. Structure of deoxyribo. nucleoproteins. I. Isolation of soluble DNP by urea treatment. Mol. Biol. (USSR) 4: 246.

Georgiev, G. P., Yu. V. Ilyin, A. S. Tikhonenko, N. N. DobBert, and L. N. ANanieva. 1967. Isolation and properties of chromosomal deoxyribonucleoproteins. Mol. Biol. (USSR) 1: 815 .

Georgtev, G. P., A. P. Ryskov, C. Coutelle, V. L. Mantieva, and E. R. Avakyan. 1972. On the structure of transcriptional unit in mammalian cells. Biochim. Biophys. Acta 259: 259.

GrLleispie, D, and S. SpieghLman. 1965. A quantitative assay for DNA-RNA hybrids with DNA immobilized on a membrane, $J$. Mol. Biol. 12: 829

HanCOCK, R. 1970. Separation by equilibrium centrifugation in $\mathrm{CsCl}$ gradients of density-labeled and normal deoxyribonucleoprotein from chromatin. $J$. Mol. Biol. 48: 347.

Hares, L. and L. Montagnier. 1971. Homology of double-stranded RNA from rat liver cells with the cellular genome. Nature New Biol. 229: 106.

ILYIN, YU. V. and G. P. Groraiev. 1969. Heterogeneity of deoxyribonucleoprotein particles as evidenced by ultracentrifugation in cesium chloride density gradient. J. Mol. Biol. 41: 299.

Ilyin, Yu. V., A. J. Varshavsky, and G. P. Georgiev. 1970. Structure of chromosomal deoxyribonucleoproteins. 3. DNP heterogeneity as evidenced by centrifugation in $\mathrm{CsCl}$ density gradient. Mol. Biol. (USSR) 4: 821.

Ilyin, YU. V., A. J. Varshavsky, U. N. Mickelsaar, and G. P. Georalev. 1971. Studies on deoxyribonucleoprotein structure. Redistribution of proteins in mix tures of deoxyribonucleoproteins DNA and RNA. Europ. J. Biochem. 22: 235.

Imaizumi, T., H. DiggelmanN, and K. ScherRer. 1973 Demonstration of globin messenger sequences in giant nuclear precursor of messenger RNA of avian erythroblasts. Proc. Nat. Acad. Sci. 70: 1122.

IтZHAKI, R. F. 1971. Arrangement of proteins in chromatin. Biochem. J. 125: 221.

Jelinek, W. and J. E. Darnele. 1972. Double-stranded regions in heterogeneous nuclear RNA from HeLa cells. Proc. Nat. Acad. Sci. 69: 2537.

Judd, B. H., M. W. Shen, and T. C. KaummanN. 1972 The anatomy and function of a segment of the $X$ chromosome of Drosophila melanogaster. Genetics 71: 139.

Lee, S. Y., J. Mendecki, and G. Brawerman. 1971. A polynucleotide segment rich in adenylic acid in the rapidly-labeled polyribosomal RNA component of mouse sarcoma 180 ascites cells. Proc. Nat. Acad. Sci. 68: 1331 .

LEPPLA, S. H., B. BJoraker, and R. M. Bock. 1968 Borohydride reduction of periodate-oxydized chain ends, p. 236. In Methods in enzymology, vol. 12B, ed L. Grossman and K. Moldave. Academic Press, New York.

Lindberg, U. and J. E. Darnell. 1970. SV-40 specific RNA in the nucleus and polyribosomes of transformed cells. Proc. Nat. Acad. Sci. 65: 1089.

Mendecki, J., S. Y. Lee, and G. Brawerman. 1972 Characteristics of the polyadenylic acid segment associated with messenger ribonucleic acid in mouse sarcoma 180 ascites cells. Biochemistry 11: 792 .

Molloy, G. R., W. L. Thomas, and J. E. Darneld. 1972a. Occurrence of uridylate-rich oligonucleotide regions in heterogeneous nuclear RNA of HeLa cells. Proc. Nat. Acad. Sci. 69: 3684.

Molloy, G. R., M. B. Sporn, D. E. Kelley, and R. P. Perry. 1972b. Localization of polyadenylic acid sequences in messenger ribonucleic acid of mammalian cells. Biochemistry 11 : 3256.

Ohlenbush H. H., B. M. Olivera, D. Tuan, and $\mathbf{N}$ Davidson. 1967. Selective dissociation of histones from calf thymus nucleoprotein. J. Mol. Biol. $25: 299$.

Pardon, J. F. and M. H. F. Wilkins. 1972. A model for supercoiled nucleohistone. J. Mol. Biol. 68: 115.

Ryskov, A. P. and G. P. Georgiev. 1970. Polyphosphate groups in the $5^{\prime}$-ends of nuclear dRNA fractions. F $E B S$ Letters 8: 186.

Ryskov, A. P., V. R. Farashyan, and G. P. Georgiev. 1972. Ribonuclease stable base sequences specific exclusively for giant dRNA. Biochim. Biophys. Acta 262: 568 . 
Ryskov, A. P., G. F. Saunders, V. R. Farashyan, and G. P. GEorgIEv. 1973. Double-helical regions in nuclearprecursor of mRNA (pre-mRNA). Biochim. Biophys. Acta 312 : 152.

SAMARINA, O. P. 1964. The distribution and properties of cytoplasmic deoxyribonucleic acid-like ribonucleic acid (messenger ribonucleic acid). Biochim. Biophys. Acta 91 : 688.

Samarina, O. P., M. I. Lerman, V. G. Tumanyan, L. N. Ananieva, and G. P. Georgiev. 1965. The characteristics of chromosomal informational RNA. Biokhimiya 30: 880 .

Scherrer, K. and L. Marcaud. 1965. Remarques sur les RNA messengers polycistroniques dans les cellules animales. Bull. Soc. Chim. Biol. 47: 1697.

1968. Messenger RNA in avian erythroblasts at the transcriptional and translation levels and the problem of regulation in animal cells. J. Cell Physiol. 72(Suppl. 1): 181.

Shearer, R. W. and B. J. MCCarthy. 1967. Evidence for ribonucleic acid molecules restricted to the cell nucleus. Biochemistry 6: 283.
Sutron, W. D. 1971. A crude nuclease preparation suitable for use in DNA reassociation experiments. Biochim. Biophys. Acta 240: 552.

SuZUkI, Y., L. P. GAGE, and D. D. Brown. 1972. The genes for silk fibroin in Bombyx mori. J. Mol. Biol. 70: 637 .

VARShavsky, A. J. and G. P. Georgiev. 1972. Clustered arrangement of histones F2al and F3 along DNA in chromosomal deoxyribonucleoproteins. Biochim. Biophys. Acta 281 : 669 .

Varshavskx, A. J., Yu. V. Ilyin, and G. P. Georgiev. 1973. Long molecules of free DNA in the sheared chromatin preparation. Molecular Biology Reports. In press.

Williamson, R., C. E. Drewienkiewicz, and J. Paul. 1973. Globin messenger sequences in high molecular weight RNA from embryonic mouse liver. Nature New Biol. 241 : 66.

Yoshikawa, M., T. Fukada, and Y. Kawada. 1964. Separation of rapidly labeled RNA of animal cells into DNA-type and ribosomal RNA-type components. Biochem. Biophys. Res. Commun. 15: 23. 